\title{
Toll-like receptor 4 (TLR4) antagonists as potential therapeutics for intestinal inflammation
}

\author{
Janine S. Y. Tam ${ }^{1}$ (D) - Janet K. Coller ${ }^{2} \cdot$ Patrick A. Hughes ${ }^{3} \cdot$ Clive A. Prestidge ${ }^{4,5} \cdot$ Joanne M. Bowen $^{1}$
}

Received: 13 August 2020 / Accepted: 27 October 2020 / Published online: 5 March 2021

(C) Indian Society of Gastroenterology 2021

\begin{abstract}
Gastrointestinal inflammation is a hallmark of highly prevalent disorders, including cancer treatment-induced mucositis and ulcerative colitis. These disorders cause debilitating symptoms, have a significant impact on quality of life, and are poorly managed. The activation of toll-like receptor 4 (TLR4) has been proposed to have a major influence on the inflammatory signalling pathways of the intestinal tract. Inhibition of TLR4 has been postulated as an effective way to treat intestinal inflammation. However, there are a limited number of studies looking into the potential of TLR4 antagonism as a therapeutic approach for intestinal inflammation. This review surveyed available literature and reported on the in vitro, ex vivo and in vivo effects of TLR4 antagonism on different models of intestinal inflammation. Of the studies reviewed, evidence suggests that there is indeed potential for TLR4 antagonists to treat inflammation, although only a limited number of studies have investigated treating intestinal inflammation with TLR4 antagonists directly. These results warrant further research into the effect of TLR4 antagonists in the intestinal tract.
\end{abstract}

Keywords Acute inflammation · Chemotherapy · Chronic inflammation · Crohn's disease - Inflammatory bowel disease · Intestinal mucositis $\cdot$ Lipopolysaccharide $\cdot$ Radiation $\cdot$ TLR4 antagonists $\cdot$ Ulcerative colitis

\section{Introduction}

Inflammation of the intestinal tract can result in acute or chronic manifestations of intestinal diseases; it may cause irritation, exposure to bacteria, and a dysregulation of the homeostatic balance. This leads to a range of debilitating symptoms that may affect patients' quality of life. Current treatment modalities used for intestinal inflammation are associated with

Janine S. Y. Tam

shuyiejanine.tam@adelaide.edu.au

1 Discipline of Physiology, Adelaide Medical School, University of Adelaide, Adelaide, South Australia 5005, Australia

2 Discipline of Pharmacology, Adelaide Medical School, University of Adelaide, Adelaide, South Australia, Australia

3 Centre for Nutrition and Gastrointestinal Diseases, Adelaide Medical School, University of Adelaide and South Australian Health and Medical Research Institute, Adelaide, Australia

4 Clinical and Health Sciences, University of South Australia, Adelaide, South Australia, Australia

5 ARC Centre of Excellence in Convergent Bio-Nano Science and Technology, Melbourne, Australia a range of disadvantages including poor efficacy and unwanted side effects. The incidence rates for intestinal inflammation have been steadily increasing around the world for the last 50 years with an increased prevalence most notable in newly industrialized nations $[1,2]$. Factors such as cell types, immunological abnormalities, tissue specificity and genetic/ environmental factors are involved in the pathogenesis of intestinal inflammation.

Toll-like receptors (TLRs) are type 1 transmembrane proteins belonging to the wider family of pattern recognition receptors, and are responsible for the recognition of a variety of molecular signals, including endogenous damage and pathogen-associated signals, damage-associated molecular patterns (DAMPs) and pathogen-associated molecular patterns (PAMPs), respectively. Both immune (dendritic cells, monocytes, mast cells, macrophages) and non-immune cells (fibroblasts, epithelial cells) express these pattern recognition receptors [3]. The pattern recognition receptor-ligand binding between DAMPs and PAMPs prompts a downstream signalling cascade, which results in the recruitment of leukocytes [3]. TLRs activate downstream signalling pathways, which originates from the toll-interleukin receptor (TIR) domaincontaining adaptor proteins such as myeloid differentiation 
primary-response protein 88 (MyD88), TIR-domain-containing adaptor protein (TIRAP), TIR domain-containing adaptor protein inducing interferon- $\beta$ (TRIF) and TRIF-related adaptor molecule (TRAM) [4]. These adaptor molecules are essential to produce inflammatory cytokines, type 1 interferons, chemokines and co-stimulatory molecules. At present, $13 \mathrm{hu}-$ man TLRs have been identified and are located on various cellular compartments (including extracellular membrane, endosome and golgi apparatus) with each TLR responding to specific stimuli $[4,5]$.

In a healthy intestinal tract, enterocytes coexist with luminal and mucosa-associated commensal bacteria without the initiation of inflammatory responses. However, the exact mechanism behind bacterial tolerance within the intestinal tract is still largely unknown. TLRs play a pivotal role in immune tolerance to intestinal microbes [6]. These immune tolerance and responses are organized by Peyer's patches, mesenteric lymph nodes and the lamina propria [7]. These lymphoid organs are populated with dendritic cells, which produce interleukin 10 (IL-10) in turn, transforming T cells into transforming growth factor- $\beta$ (TGF- $\beta$ ) [7]. The production of these cytokines leads to immune tolerance and homeostasis, as well as unnecessary inflammation [7]. This suggests that TLR4 signalling has an effect not only on immune responses but also on the balance of the intestinal microbial ecosystem $[8,9]$.

In contrast, during conditions of stress (such as disease) in the intestinal tract, inflammatory cytokines are released from enterocytes and mucosal immune cells responding to the stimulation of TLRs [10]. This leads to apoptosis and reduced proliferation of enterocytes, which in turn promotes translocation of bacteria into the lamina propria, exacerbating intestinal inflammation [10]. One of the most well-characterized TLRs is TLR4, which has been shown to be involved in homeostasis, apoptosis, intestinal inflammation and inflammatory bowel disease [11]. The focus of this review will therefore be based on the role of TLR4 antagonism in inflammatory conditions with the purpose of generating a hypothesis to support the use of TLR4 antagonists in intestinal inflammation.

\section{Toll-like receptor 4 activation and signalling}

In 1997, toll proteins in Drosophila were discovered to mediate protection against fungal infections [12]. Toll proteins in Drosophila were activated by fungi and Gram-positive bacteria, which do not contain lipopolysaccharide (LPS). They do, however, trigger a toxic shock response that is similarly induced by LPS [12]. This then led to research focusing on the now established TLR4-LPS signalling cascade. This early work also suggests a much broader role of TLR in homeostasis, tissue repair and immune defence [13].
TLR4 is an intra- and extracellular receptor expressed on endosomes and cytoplasmic membranes, which recognizes PAMPs (flagellin and LPS) and DAMPS (calprotectin, S100A8/9 HMGB1 and HSP70) through its co-receptors MD2 and CD14 [14, 15]. In addition, TLR4 has recently shown to be activated by certain pharmacological agents, including chemotherapeutic agents (paclitaxel). TLR4 is located on many different cell types (endothelial cells, lymphocytes, cardiac myocytes and glial cells) throughout the body [16-18]. In the intestine, TLR4 is expressed on antigenpresenting cells such as macrophages and dendritic cells, and on enterocytes and lymphocytes [19]. TLR4 consists of leucine-rich repeats (LRRs) with a horseshoe-like shape made up of 839 amino acids. The complex ligand specificity of the TLR4/MD2 complex is composed of two antiparallel $\beta$ sheets, which form a large hydrophobic pocket in MD2 [20]. LPS is able to bind to this hydrophobic pocket through its lipid chains, which are completely buried in the MD2 hydrophobic pocket [20]. However, one of these lipid chains is partially exposed to the outer surface, which allows some interaction with TLR4 [20]. These hydrophilic and hydrophobic interactions between LPS and the TLR4/MD2 complex mediate the dimerization of extracellular domains in the TLR4, thus triggering a downstream signalling cascade leading to the release of pro-inflammatory cytokines [20]. A study by Abreu et al. [21] discovered that increases in TLR4 expression alone would not result in a reaction from LPS without the accompanying expression of MD2. In the study, they challenged different intestinal epithelial cell lines (Caco-2, T84, HT-29) with LPS and found that a decreased expression of TLR4 and MD2 correlated with intestinal epithelial protection against proinflammatory gene expression in response to bacterial LPS. It was concluded that careful regulation of both TLR4 and MD2 is necessary to maintain homeostasis in the intestinal tract due to it being continuously exposed to high concentrations of bacteria.

Upon stimulation, TLR4 will activate two signalling pathways, the TRIF-dependent pathway (Fig. 1) and the MyD88dependent pathway (Fig. 2). In the TRIF-dependent pathway, TLR4 heterodimers recruit TRAM, which is needed to activate TRIF, resulting in the binding of TRIF with TNF receptor-associated factor 3 (TRAF3) and TRAF6 for binding with RIP, a receptor-interacting serine-threonine kinase 1 protein. Subsequently, this leads to the activation of nuclear factor kappa-light-chain-enhancer of activated B cells (NF-KB). The TRIF-activated pathway leads to the activation of interferon regulatory transcription factor 3 (IRF3) by TANK-binding kinase 1 (TBK1) and inhibitor of NF-kB-kinase complex stimulation (IKK), which results in the production of type 1 interferons and anti-inflammatory cytokines (such as IL-10).

In the MyD88 signalling pathway, TLR4 heterodimers will bind to MyD88, which results in the formation of IRAK (interleukin 1 receptor-associated kinases) and TRAF6 
complexes [14]. Formation of IRAK and TRAF6 complexes leads to a downstream signalling cascade. Various other complexes such as TAK1, TAB1/2/3, MAP kinases and IKB will be phosphorylated or activated to allow the translocation of $\mathrm{NF}-\mathrm{KB}$ into the nucleus, ultimately driving the transcription of cytokine genes (such as TNFs, ILs and chemokines) to regulate pro-inflammatory responses [14, 22].

Dysregulation of TLR4 signalling has been linked to the development of a variety of inflammatory diseases. Studies have investigated functional genetic variants of TLR4 and their impact on LPS signalling response. A study by Hold et al. found that cells carrying TLR4 D299G and T399I variants, when stimulated with LPS, had a sixfold lower expression of NF-KB compared to wild-type TLR4 [23]. Ferwerda et al. demonstrated that patients carrying a variant at position 299 (Gly) but not at position 399 (Ile) had a stronger proinflammatory cytokine response with increased TNF- $\alpha$ levels in whole blood samples when stimulated with LPS compared to patients carrying wild-type TLR4 alleles at both positions [24]. Weinstein et al. showed that the same TLR4 variants in patients with acute ischemic stroke are associated with worse neurological outcomes and alterations in systemic markers of inflammation [25]. This dramatic difference in cytokine expression caused by dysregulation of TLR4 signalling due to genetic polymorphisms will affect a person's ability to respond to LPS leading to a dysregulated immune response to infection. Considering that TLR4 downstream signalling plays a pathological role in inflammation, using antagonists or inhibitors to target TLR4 signalling may be beneficial in treating inflammatory disorders.

\section{TLR4-mediated intestinal inflammation}

An important component of immunity and host-microbial interactions in the intestinal tract is the recognition of DAMPs,
Fig. 1 Pathogen-associated molecular pattern toll-like receptor 4 signalling pathway in an enterocyte. $L P S$

Lipopolysaccharide, TLR Tolllike receptor, TIRAP TIR domain-containing adaptor protein, TRAM TRIF-related adaptor molecule, $M y D 88$ Myeloid differentiation primaryresponse protein $88, I K K$ Inhibitor of NF-kB-kinase complex, TRIF TIR -domaincontaining adaptor protein inducing interferon- $\beta, T B K 1$ TANKbinding kinase $1, N F-\kappa B$ Nuclear factor-kappaB, $I R F 3$ Interferon regulatory transcription factor 3

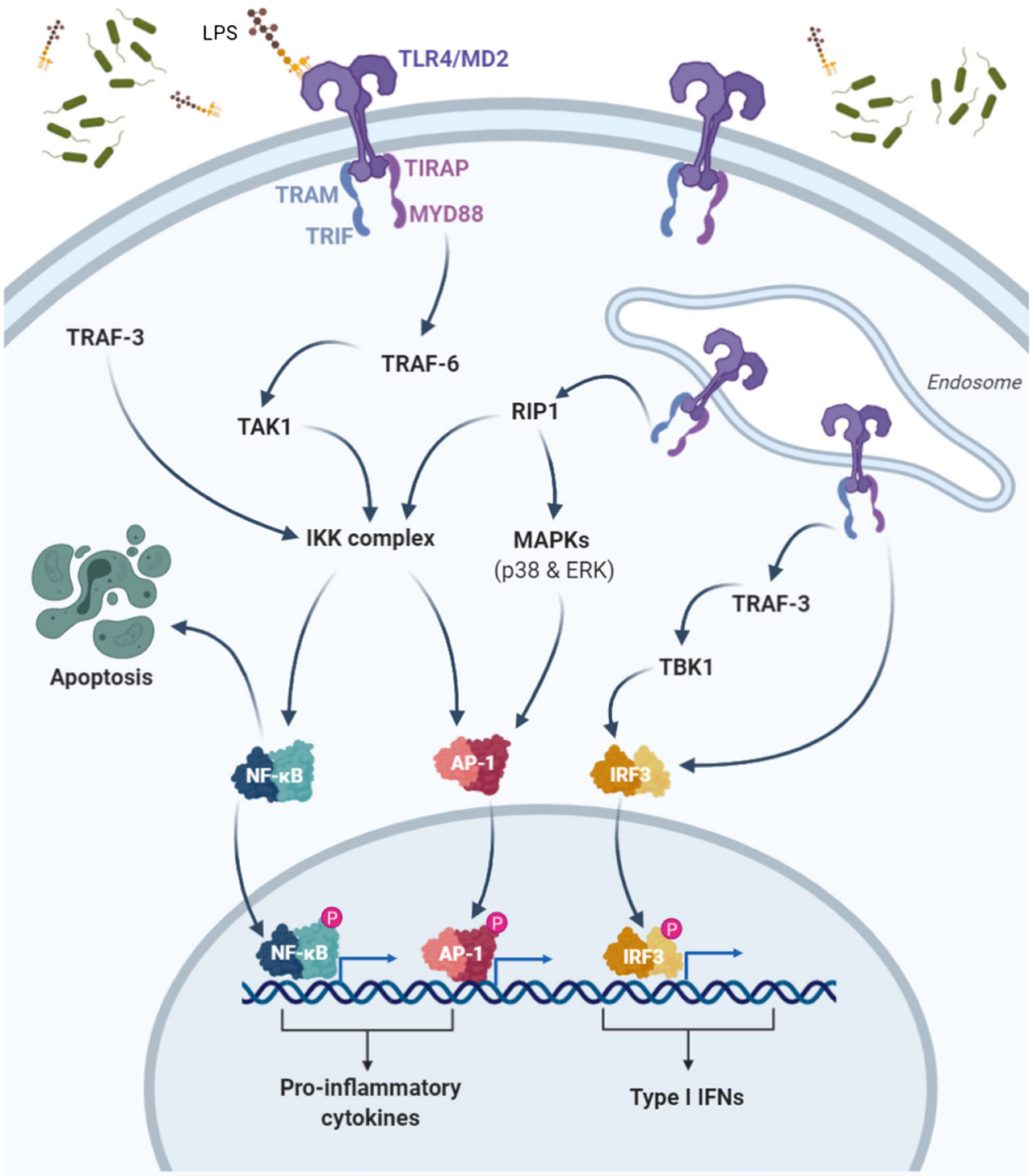


Fig. 2 Toll-like receptor 4 activation by damage-associated molecular patterns from tissue damage leads to a downstream signalling pathway, which induces inflammatory gene expression. DAMPs Damageassociated molecular patterns, TLR Toll-like receptor, TRAM TRIF-related adaptor molecule, TRIF TIR -domain-containing adaptor protein inducing interferon- $\beta$, TIRAP TIR domain-containing adaptor protein, $M y D 88$ Myeloid differentiation primary-response protein 88 , IKK Inhibitor of NF-kBkinase complex, IRF3 Interferon regulatory transcription factor $3, N F-\kappa B$ Nuclear factorkappaB, IL Interleukin

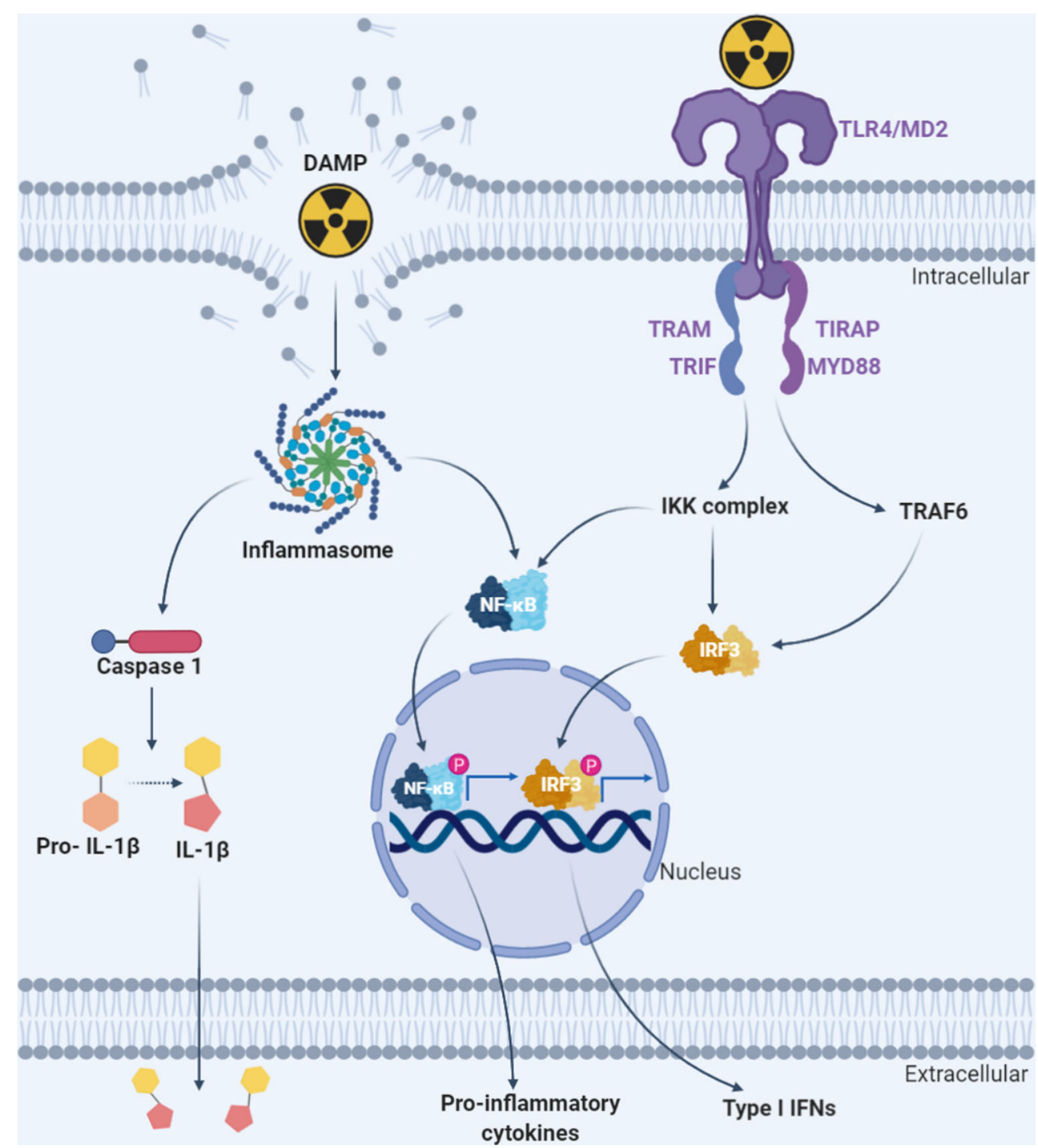

PAMPs and endogenous ligands by TLR4 expressed on the enterocytes and antigen-presenting cells. Any imbalance from this interaction may contribute to the pathogenesis of inflammation within the intestinal tract [26]. There has also been substantial evidence indicating the involvement of TLR4 in intestinal inflammatory diseases such as ulcerative colitis (UC), Crohn's disease (CD) and intestinal mucositis (IM). It was reported that, in the colonic mucosa of patients with UC and CD, a significant increase in TLR4 mRNA and protein expression was observed compared to healthy controls [27, 28]. However, this may be due to the increased influx of TLR4 expressing innate immune cells. There is also mounting evidence that TLR4 polymorphism is associated with the development of $U C$ and $C D$, whereby the allele frequencies of the TLR4 Asp299Gly polymorphism were discovered to be significantly higher in UC and CD patients [29].

There have also been several studies using animal models of acute intestinal inflammation. TLR4 expression is strongly upregulated in animal models induced with colitis [30]. Animal models with TLR4 knocked-out were observed to be protected from colitis or colon tumorigenesis by preventing the downstream signalling pathways that induce colitis [30]. For example, TLR4 knockout (KO) mice induced with acute colitis had a decrease in COX-2 expression, prostaglandin production and NF-KB signalling, which lead to a significant reduction of acute inflammatory cells and therefore significantly reduced acute inflammation in the intestinal tract [31]. Other studies have observed an increase in pathogenic E. coli and a decrease in beneficial intestinal microbiomes (Bifidobacterium spp. and Lactobacillus spp.) in a DSSinduced mouse model, which may be associated with an increase in the TLR4 expression observed in the colon of the animals [8], while another study using TLR4 KO mice showed a reduction in pathogenic $E$. coli compared to the DSS-induced wild-type mice, which showed a tenfold increase in pathogenic E. coli [9]. These TLR4-deficient mice 
also displayed reduced disease activity index and histopathological scoring.

It therefore stands to reason that, by inhibiting TLR4, a protective effect from intestinal inflammation will be induced. Recent research has shown that, by inhibiting TLR4 using antagonists such as paeoniflorin, monoclonal antibodies and CRX-526, DSS-induced intestinal inflammation was attenuated with a significant reduction in disease activity and histopathological scoring [32-34]. However, other studies have discovered that there was no protective effect observed in the clinical symptoms and histology scores when blocking TLR4 during chronic intestinal inflammation [35] despite the opposite results observed during acute intestinal inflammation [31], most likely due to the low involvement of innate immune cells in chronic compared to acute inflammation [36].

\section{TLR4 antagonists as a potential therapeutic alternative for treatment of intestinal inflammation}

Inflammatory bowel disease (IBD) (consisting of UC and $\mathrm{CD}$ ) is known as a non-specific, chronic gastrointestinal inflammatory disorder [37], with periods of disease activation and remission, and in some cases progressive disease [38]. It is considered an autoimmune disease due to the combined effect of genetic factors and abnormal immune responses to the intestinal bacteria and other foreign substances [37]. In addition, one of the most serious complications that IBD patients encounter is colorectal cancer, which accounts for increased mortality rates associated with UC [39]. The severity of inflammation in the intestinal tract also correlates with the risk of colorectal cancer in patients with IBD [39].

Severe intestinal inflammation leads to a range of debilitating symptoms that significantly affects patient quality of life. Current treatment modalities for intestinal inflammation are associated with a range of disadvantages including poor efficacy and unwanted side effects. The TLR4 signalling cascade also plays an important role in intestinal inflammation, with its extracellular and intracellular components being attractive therapeutic targets for the treatment of both acute and chronic intestinal inflammation. The link between intestinal inflammation and colon cancer also offers the possibility of identifying and developing novel ways to prevent cancer.

The incidence rates for IBD have been steadily increasing around the world for the last 50 years with the majority of cases occurring in westernized and industrialized countries $[1,40]$. IBD is a chronic and lifelong condition that has no cure and requires a lifetime of care. It has a significant effect on patient quality of life [41, 42]. However, UC and CD are clinically distinct diseases and known to have different anatomical, clinical and histological features [43].

Presently, the etiology and pathogenesis for IBD remain largely unknown [43], with a plausible hypothesis for the etiology of IBD being the unregulated activation of both the body's innate and adaptive immune systems, potentially in response to resident gut microbes. This immune response may be mediated by the innate immune receptor TLR4 in response to luminal antigens (fungi, bacteria) in the intestinal tract [43]. Treatment approaches include aminosalicylates, corticosteroids and antibiotics $[44,45]$.

As previously stated, patients with IBD are at higher risk of developing colorectal cancer, and a common complication of cancer treatment is intestinal mucositis (IM), occurring in $40 \%$ of patients who receive a standard dose of chemotherapy and $100 \%$ of patients who are receiving high doses of chemotherapy [46, 47]. IM is the ulceration and inflammation of the mucosa in the intestinal tract caused by chemotherapy and radiation for cancer, and is an acute form of intestinal inflammation [48].

Unfortunately, the gastrointestinal tract is particularly susceptible to the devastating effects of chemotherapy and radiation. TLR4 is the main receptor that detects DAMPs and responds to tissue damage in the intestinal tract [49]. The cytotoxic effects of chemotherapy and radiation on both normal and malignant cells cause the release of DAMPs. This produces a sustained innate immune activation, which develops into the mucosal inflammation seen in patients with repeating cycles of chemotherapy and radiation treatments [49]. While mucositis has been recognized as a major dose-limiting toxicity for decades, there is yet to be an effective treatment to manage intestinal inflammation. Pre-clinical studies have focused on inhibition of inflammation via multiple mechanisms, or accelerating healing with growth factors [50].

IM has a significant impact on the quality of life of patients whereby the average number of days a patient suffering from IM needs to be hospitalized is 3 times more than the 4 days required by patients not suffering from IM [51]. This increased length of stay increases the strain on hospital resources [51]. Patients also suffer from symptoms such as vomiting, abdominal pain and severe diarrhea. In certain cases, the symptoms of IM will cause patients to require a dose reduction, delay or even discontinuation of their regimen, which will affect the patient's survival [52]. To date, studies have shown a link between TLR4/MD2 signalling and the development of IBD and IM [34, 53]. TLR4 antagonists show potential as therapeutic agents in both the settings. However, the majority of studies have focused mainly on sepsis models as well as diseases and infections unrelated to the development of intestinal inflammation, leaving a significant gap in the literature. 
TLR4 is overexpressed in both UC (fold increase: 2.33) and $C D$ (fold increase: 1.71) [27, 54, 55]. In IBD, abnormal signal transmission mediated by the upregulation of TLR4 promotes the sustained release of inflammatory cytokines (IL-6, TNF- $\alpha$ ). This, in turn, develops and persists as intestinal inflammation. Only low levels of TLR4 and MD2 are expressed on the intestinal epithelium and very little was known about their regulation on intestinal epithelial cells. However, it was established that, during inflammation, expression of both TLR4 and MD2 is increased. It was later discovered by Abreu et al. [56] that the expression of TLR4 and MD2 in the intestinal tract is also regulated by immune-mediated signals. There was an increase in TLR4/MD2 expression when the intestinal epithelial cell lines (T84, HT-29) were exposed to pro-inflammatory cytokines (IFN- $\gamma$, TNF- $\alpha$ ) highlighting the potential link between the innate and adaptive immune systems in intestinal epithelial cells only in response to pathogenic organisms. Another study by Ungaro et al. has also shown that the inflammation in IBD is decreased in TLR4-deficient mice [35]. However, the study also found that TLR4-deficient mice were unable to undergo mucosal healing and demonstrated decreased epithelial cell proliferation [35]. This shows that TLR4 serves as a mediator for both mucosal healing and inflammation in the intestinal tract.

A similar pattern can also be observed in IM. A study by Wardill et al. has shown that genetic deletion of TLR4 from mice was able to improve chemotherapy-induced gut toxicity and pain [53]. TLR4 KO mice had reduced diarrhea and weight loss compared to wild-type mice [53]. The TLR4 KO mice also exhibited a muted inflammatory response, with no significant increase in IL-1 $\beta$, IL-6 or TNF- $\alpha$, compared to their wild-type counterparts [53].

These studies point out the critical role of TLR4 in regulating inflammation in the intestinal tract, and by targeting and inhibiting TLR4, the outcome of intestinal inflammation and its consequence may be prevented. However, careful selection of TLR4 elimination vs. selective or temporary inhibition as a therapeutic is needed since TLR4 has beneficial effects for mucosal healing and homeostasis.

\section{TLR4 antagonists}

Targeting TLR4 could represent a potential approach to regulate immune responses and treat inflammation. However, any potential therapeutic agent must be able to block the harmful effects of TLR4 activation without negatively affecting the host's defence functions. Currently, many different antagonists are being investigated for their potential in managing inflammatory-based diseases and settings, summarized in Table 1.

\section{Naturally occurring}

The first naturally occurring TLR4 antagonist discovered was from a photosynthetic Gram-negative bacterium that was nonpathogenic, known as Rhodobacter sphaeroides [57]. The LPS produced from this bacterium, known as Rhodobacter sphaeroides lipid A (RsDPLA), was non-toxic towards murine and human cells and was able to compete with toxic LPS for binding sites. RsDPLA was also able to interact with the TLR4/MD2 complex found in rodents and humans with antagonistic effects [58]. Further in vitro and in vivo studies on the LPS produced by Rhodobacter sphaeroides and other bacteria/cyanobacteria have shown potent antagonistic activity of this type of LPS in murine and human cells as well as preventing endotoxic shock in mice.

Additionally, traditional Asian medicines produced from plants, including curcumin, turmeric and a variety of herbs, provide a rich and natural source of molecules which are being investigated for bio-activities that act as TLR4 antagonists [59, 60]. The modulation of TLR4 using herbal extracts promoted a large area of research to determine their pharmacological potential. It was found that certain bio-actives from bacteria or plants had a positive relationship against sepsis and septic shock [61-63]. These bio-actives were also discovered to have positive relationships against inflammatory diseases such as Alzheimer's, arthritis and inflammatory bowel diseases [35, 64, 65]. A summary of research conducted on some of these naturally sourced TLR4 antagonists can be found in Table 1 . Although the main focus of this study is on the therapeutic potentials of TLR4 antagonists on intestinal inflammation, there are a limited number of studies, which used intestinal inflammation as a disease model.

\section{Synthetic}

Although there are many plant-based products capable of targeting and inhibiting TLR4 in vitro and in vivo in both rodent and human models, these do not possess the necessary stability and target specificity to be considered a potential therapeutic option compared to products and molecules extracted from microorganisms [59], which was why the molecules produced from microorganisms such as Rhodobacter sphaeroides have been used as a model to create synthetic antagonists. RsDPLA was used to design the synthetic TLR4 antagonists eritoran (E5564) and E5531 [80, 81]. E5531 was a first-generation lipid A analogue synthesized as part of a program to develop therapeutic agents for septic shock [82], while eritoran (E5564) is a second-generation lipid A analogue designed for the same purpose but was found to be more potent in its antiendotoxin effects, longer lasting and easier to manufacture 
Table 1 Summary of the effect of natural TLR4 antagonists in previous pre-clinical in vitro, in vivo and in silico studies

\begin{tabular}{ll}
\hline Study & Study model \\
\hline Qureshi et al. [61] & $\begin{array}{l}\text { Bacterial sepsis } \\
\text { In vivo: BDF1 mice injected with LPS } \\
(1 \mu \mathrm{g})\end{array}$ \\
Kirikae et al. [66] & $\begin{array}{l}\text { In vitro inflammation model } \\
\text { In vitro: mouse macrophage-like J774.1 cell } \\
\text { line challenged with LPS }\end{array}$
\end{tabular}

Anwar et al. [58] In silico Molecular dynamics simulation

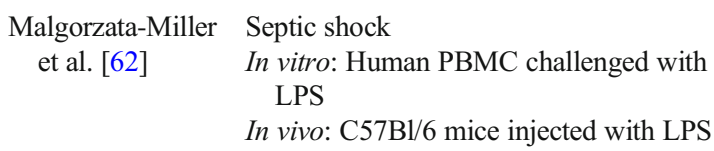

De Paola et al. [67] Amyotrophic lateral sclerosis In vitro: Motor neuron/glia co-cultures In vivo: Wobbler mice

Balducci et al. [64] Alzheimer's disease In vivo: $\mathrm{C} 57 \mathrm{Bl} / 6$ mice

Iori et al. [68] Seizures

In vivo: $\mathrm{C} 57 \mathrm{Bl} / 6$ mice

Yao et al. [69] Inflammatory bowel disease

In vitro: Sprague-Dawley rats injected with 2,4,6-trinitro-benzene sulfonic acid
Lipooligosaccharide (LOS) from Bartonella quintana (BqLOS)

Rhodobacter sphaeroides lipid A (RsDPLA)

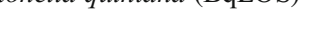

LPS from Oscillatoria Planktothrix FP1 (Cyp/VB3323)

Probiotics, Golden bifid
Outcome

RsDPLA (100 $\mu$ g, i.p.) pre-treatment was associated with $91 \%$ inhibition of LPS-induced response as measured by serum TNF- $\alpha$ concentration $(246 \pm 95 \mathrm{pg} / \mathrm{mL}$ vs. $2653 \pm 286 \mathrm{pg} / \mathrm{mL}$ vehicle control).

RsDPLA treatment decreased LPS response in a dose-dependent fashion as measured by TNF and IL-6 secretion (65\% inhibition at $1: 3$ and $100 \%$ at $1: 62$ LPS:RsDPLA ratio). Mechanism proposed to be through binding of CD14 receptor.

Simulation predicted inhibitory behavior of RsDPLA on the TLR4/MD2 complex in rodents and humans.

Human PBMCs pre-incubated with BqLOS $(100 \mathrm{ng} / \mathrm{mL})$ was associated with inhibition of LPS-induced response measured by supernatant concentration of IL- $1 \beta, \mathrm{TNF}-\alpha$, IL-6, IL-8 $(p<0.001)$. Mice pre-treated with BqLOS $(100 \mu \mathrm{g})$ had improved survival rates.

In vitro:

Cells exposed to LPS $(1 \mu \mathrm{g} / \mathrm{mL})$ reduced viability by $30.8 \pm 11.9 \%$ ( $p<0.001$ vs. control). This toxic effect was reduced by VB3323 $(20 \mu \mathrm{g} / \mathrm{mL})$ which almost completely restored motor neuron viability in the cells $(91.3 \pm 9.9 \%$ with $p<0.001$ vs. LPS).

In vivo:

Wobbler mouse with spontaneous motor neuron degeneration chronically treated with VB3323 (5 mg/kg/d i.p., final concentration $0.5 \mathrm{mg} / \mathrm{mL}$ ) displayed decreased microglial activation and morphological alterations of spinal cord neurons; and better performance in the paw abnormality and grip-strength tests.

Amyloid- $\beta$ oligomers $(\mathrm{A} \beta \mathrm{O})$ injection (7.5 $\mu \mathrm{L}$ at $1 \mu \mathrm{M})$ rapidly activated glial cells and induced a memory establishment deficit. When treated with CyP $(10 \mu \mathrm{g}$, $\mathrm{ICV}$ ) before $\mathrm{A} \beta \mathrm{O}$, the memory deficit was prevented $(p=0.0055)$.

Carbamazepine (CBZ) is an anticonvulsant to treat neuropsychiatric disorders. Mice treated with CyP (1 mg/mouse, i.p.) + CBZ (20 mg/mouse, in food) during disease onset. CBZ-treated mice displayed a three-fold higher seizure frequency compared to CyP-treated mice $(p<0.01)$. TLR4 antagonism by $\mathrm{CyP}$ was effective in delaying seizure onset and reduced recurrence in the established murine model of acquired epilepsy.

Rats treated with the probiotics had a significantly lower disease activity $(p<$ $0.05)$, histopathological score $(p<0.05)$ and 
Table 1 (continued)

\begin{tabular}{ll}
\hline Study & Study model \\
\hline Chu et al. [70] & $\begin{array}{l}\text { In silico } \\
\text { Docking analysis }\end{array}$ \\
& \\
& $\begin{array}{l}\text { Bacterial infection } \\
\text { In vivo: Balb/c mice challenged with } \\
\text { Salmonella typhimurium and bacterial } \\
\text { endotoxin }\end{array}$
\end{tabular}

Liang et al. [71] In vitro inflammation model

In vitro: THP-1 human monocyte cells challenged with LPS

Sepsis

In vivo: $\mathrm{C} 57 \mathrm{Bl} / 6$ mice administered with LPS
Berberine, extracted from the herb Huang Lian (Rhizoma coptidis)

Sparstolonin B (SsnB) extracted from a Chinese herb (Sparganium stoloniferum)
Outcome

inflammatory cytokine levels (TNF- $\alpha$ and IL-1 $\beta, p<0.05)$ compared to control groups.

Docking analysis suggested that 3 berberine molecules were able to bind to MD2 and block TLR4/NF-KB downstream signalling. Binding free energies of the 3 berberine molecules was $7.70,-7.33$ and $6.75 \mathrm{kcal} / \mathrm{mol}$, respectively.

Mice treated with $2 \mathrm{EU} / \mathrm{mL}$ endotoxin solution (i.p.) had a lethal rate of $80 \%$. When treated with berberine at different doses $(0.13,0.16$ and $0.20 \mathrm{~g} / \mathrm{kg}$ ) after endotoxin administration, mice had survival rate of $50 \%, 50 \%$ and $60 \%$ respectively. Average death time of each mouse group treated with berberine was significantly better compared to mice only exposed to LPS $(p<0.05)$.

In vitro:

SsnB $(100 \mu \mathrm{M})$ inhibited LPS-induced $(50 \mathrm{ng} / \mathrm{mL})$ response as measured by an 18 -fold decrease in TNF- $\alpha$ and 10 -fold decrease in IL-6 expression levels vs. LPS-treated cells only. Mechanism proposed to be through binding of the CD14/TLR4 receptor.

In vivo:

Mice co-treated with LPS (100 $\mu \mathrm{g} /$ mouse $)$ and $\mathrm{SsnB}(100 \mu \mathrm{g} / \mathrm{mouse})$ displayed lower expression of TNF- $\alpha(p=0.0075)$, IL-6 ( $p=$ $0.1077)$ and IL-1 $\beta(p<0.0001)$ vs.

LPS-treated mice. SsnB was able to suppress inflammation induced by LPS by attenuating the TLR4-mediated activation of NF-kB.

Parthenolide (PTL), extracted from 3 and $12 \mu \mathrm{M}$ PTL significantly decreased

In vitro: THP-1 cells treated with LPS the plant feverfew (Tanacetum parthenium) pro-inflammatory cytokine expression and diminished LPS-induced $(1 \mu \mathrm{g} / \mathrm{mL})$ TLR4 expression compared to LPS-treated group $(p<0.01)$. PTL was able to inhibit the expression of these cytokines by blocking the TLR4 which in turn blocks the subsequent downstream signalling cascade.

In vitro:

At $3 \mathrm{~h}$ and $6 \mathrm{~h}$, AS cells pre-treated with PTL $(40 \mu \mathrm{M})$ had decreased IL-8 secretion vs non-treated cells $(p=0.02$ and 0.03 , respectively).

In vivo:

LPS (25 ng, intratracheally)-treated mice had increased polymorphonuclear leukocytes (PMN) $(9 \pm 1.54 \%$ at $1 \mathrm{~h}, 38.8 \pm 7.23 \%$ at $3 \mathrm{~h}$ and $63 \pm 6.0 \%$ at $8 \mathrm{~h}$ ). When co-treated with PTL $(3 \mu \mathrm{g} / \mathrm{g})$, a decrease in PMN \% at $8 \mathrm{~h}$ was observed $(p=0.006)$. Proposed mechanism of action for PTL was NF-kB-dependent inhibition of cellular responses.

Curcumin, extracted from the turmeric plant (Curcuma longa)
$40 \%$ inhibition of TLR4/MD2 complex observed at approximately equimolar concentration of curcumin and MD2 in presence of 
Table 1 (continued)

\begin{tabular}{ll}
\hline Study & Study model \\
\hline & \\
Zhu et al. [75] & $\begin{array}{l}\text { Traumatic brain injury (TBI) } \\
\text { In vivo: Feeney weight-drop contusion } \\
\text { model on C57B1/6 mice }\end{array}$
\end{tabular}

model on $\mathrm{C} 57 \mathrm{Bl} / 6$ mice

Zhang et al. [76] Acute lung injury

In vivo: $\mathrm{BALB} / \mathrm{c}$ mice with injury induced by LPS

Wang et al. [63] Sepsis

In vivo: Cecal ligation and puncture (CLP) model of mice

Li et al. [77]

Acute respiratory distress syndrome In vivo: $\mathrm{BALB} / \mathrm{c}$ mice with LPS administered intranasally to induce lung injury

Lee et al. [78] In vitro inflammation model

In vitro: Bone marrow cells isolated from C57Bl/6 mice challenged with LPS

Yuan et al. [65] Arthritis

In vivo: $\mathrm{C} 57 \mathrm{Bl} / 6$ mice with induced adjuvant arthritis
Atractylenolide I (AO-I/ AT-I) extracted from the Chinese herb Cang Zhu (Rhizoma Atractylodis macrocephalae)

Asiatic acid (AA) extracted from the plant Gotu Kola/Pennywort (Centella asiatica)

Celastrol extracted from the plant Thunder God Vine (Tripterygium wilfordii)
Outcome

LPS. Cells co-treated with LPS

$(100 \mathrm{ng} / \mathrm{mL})$ and higher doses of curcumin $(0-20 \mu \mathrm{M})$ showed no difference in NF- $\mathrm{kB}$ activity.

Injured brain tissue had a significant increase in TLR4 expression vs. sham control brains $24 \mathrm{~h}$ post-trauma $(p<0.01)$. Curcumin $(100$ and $200 \mathrm{mg} / \mathrm{kg}$ ) administered post-trauma reduced TLR4 expression and had lower neurological deficit scores and brain water content vs, vehicle-treated mice with $p<0.01$ and $p<0.05$, respectively. A decrease in concentrations of inflammatory mediators (IL-1 $\beta$, IL-6, TNF- $\alpha$, MCP-1) vs. vehicle-treated mice $(p<0.01)$ was also observed.

LPS $(10 \mu \mathrm{g})$-treated mice displayed pathological changes: inflammatory cells infiltration, interalveolar septal thickening and edema which were attenuated in co-treated mice (LPS + AO-I at 5, 10 and $20 \mathrm{mg} / \mathrm{kg}$ ). MPO activity and inflammatory cell infiltrate were reduced in co-treated mice $(5 \mathrm{mg} / \mathrm{kg}: p<0.01,10 \mathrm{mg} / \mathrm{kg}: p<0.01$ and $20 \mathrm{mg} / \mathrm{kg}: p<0.01)$ and $(5 \mathrm{mg} / \mathrm{kg}: p<$ $0.05,10 \mathrm{mg} / \mathrm{kg}: p<0.01$ and $20 \mathrm{mg} / \mathrm{kg}: p<$ $0.01)$ vs. LPS-treated mice, respectively.

Survival of mice increased with AT-I dose at 10,20 and $40 \mathrm{mg} / \mathrm{kg}$ (i.p.) $(p<0.05, p<0.01$, $p<0.01$, respectively) vs. control, respectively. AT-I-treated mice took a shorter time to return to normal temperature $(p<0.05)$ and displayed dose-dependent decrease in pro-inflammatory cytokines TNF- $\alpha$ and IL-6 ( $p<0.05, p<0.01, p<0.01$, respectively). Decrease in white blood cells $(p<0.05)$ and IL- $1 \beta(p<0.05$ and $p<0.01$, respectively) was observed at 20 and $40 \mathrm{mg} / \mathrm{kg}$ doses.

LPS-treated mice displayed increased lung wet/dry weight ratio, inflammatory cell infiltrate and MPO activity. Co-treated mice (LPS + AA at 25, 50 and $100 \mathrm{mg} / \mathrm{kg}$ ) displayed decreased lung wet/dry weight ratio $(p<0.05, p<0.01, p<0.01$, respectively) inflammatory cell infiltrate $(p<0.05, p<$ $0.01, p<0.01$, respectively) and MPO activity $(p<0.01, p<0.01, p<0.01$, respectively) vs. LPS group.

Celastrol $(0.1,0.5$ and $1 \mu \mathrm{M})$ inhibited LPS-induced $(10 \mathrm{ng} / \mathrm{mL})$ responses measured by TNF- $\alpha$, IL-6, IL-12 and IL- $1 \beta$ at mRNA and protein levels $(p<0.05)$.

Confocal imaging analysis of celastrol demonstrated decreased co-localisation of fluorescent LPS with MD2.

Celastrol $(0.5 \mathrm{mg} / \mathrm{kg})$ improved clinical outcome via clinical and histopathological scoring vs. non-treated mice $(p<0.01)$. Decreased expression of TNF- $\alpha$ (1.9-fold) 
Table 1 (continued)

\begin{tabular}{|c|c|c|c|}
\hline Study & Study model & TLR4 antagonist & Outcome \\
\hline & & & $\begin{array}{l}\text { and IL-6 ( } 3.1 \text {-fold) in celastrol treated mice } \\
\text { vs. non-treated mice. }\end{array}$ \\
\hline Cho et al. [79] & $\begin{array}{l}\text { In vitro inflammation model } \\
\text { In vitro: RAW } 264.7 \text { cells challenged with } \\
\quad \text { LPS }\end{array}$ & $\begin{array}{l}\text { Xanthohumol }(\mathrm{XN}) \text { extracted from } \\
\text { the plant Hops (Humulus } \\
\text { lupulus) }\end{array}$ & $\begin{array}{l}\text { Cells co-treated with LPS }(0.1-0.5 \mu \mathrm{g} / \mathrm{mL}) \\
\text { and } \mathrm{XN}(0.5,1,2.5 \text { and } 5 \mu \mathrm{g} / \mathrm{mL}) \text { displayed } \\
\text { a dose-dependent decrease in NO levels }(2.5 \\
\text { and } 5 \mu \mathrm{g} / \mathrm{mL}, p<0.01 \mathrm{vs} \text {. LPS group), } \\
\text { TNF- } \alpha(2.5 \text { and } 5 \mu \mathrm{g} / \mathrm{mL}, p<0.01 \mathrm{vs} \text {. LPS } \\
\text { group) and IL- } 1 \beta(1,2.5 \text { and } 5 \mu \mathrm{g} / \mathrm{mL}, p< \\
0.01 \mathrm{vs.} \mathrm{LPS} \mathrm{group).}\end{array}$ \\
\hline Ungaro et al. [35] & $\begin{array}{l}\text { Inflammatory bowel disease } \\
\text { C57Bl/6J mice with dextran sulphate } \\
\text { sodium (DSS) administered in drinking } \\
\text { water. }\end{array}$ & IgG2b monoclonal antibody & $\begin{array}{l}\text { Mice co-treated with DSS }(2.5 \%) \text { and IgG2b } \\
(20 \mathrm{mg} / \mathrm{kg}) \text { displayed decrease in expres- } \\
\text { sion of TNF- } \alpha(141.5 \pm 16.3 \mathrm{pg} / \mathrm{mL} \text { vs. } 336 \pm \\
53.8 \mathrm{pg} / \mathrm{mL}, p<0.01), \mathrm{IL}-6(4816 \pm \\
145.5 \mathrm{pg} / \mathrm{mL} \text { vs. } 5850.4 \pm 144.4 \mathrm{pg} / \mathrm{mL}, p< \\
0.01) \text { and } \% \text { dendritic cells in the lamina } \\
\text { propria }(3.4 \pm 0.7 \text { vs. } 8.7 \pm 0.4 \%, p<0.05) \text { vs. } \\
\text { control. No difference in DAI scoring vs. } \\
\text { control }(1.28 \pm 0.19 \text { vs. } 1.33 \pm 0.23, p=0.42 \\
\text { maximum score: } 4) .\end{array}$ \\
\hline Zhang et al. [32] & $\begin{array}{l}\text { Inflammatory bowel disease } \\
\text { C57Bl/6 mice with dextran sulphate sodium } \\
\text { (DSS) administered in drinking water. }\end{array}$ & $\begin{array}{l}\text { Paeoniflorin extracted from peony } \\
\text { root }\end{array}$ & $\begin{array}{l}\text { Mice pre- or co-treated with paeoniflorin } \\
(50 \mathrm{mg} / \mathrm{kg}) \text { and DSS }(4 \%) \text { suppressed } \\
\text { weight loss: Pre-paeoniflorin at day } 7(p< \\
0.05), \text { co-paeoniflorin at days } 5-6(p<0.05) \text {, } \\
\text { day } 7(p<0.001) \text {; Diarrhea/bloody diarrhea: } \\
\text { Pre-paeoniflorin at days } 5(p<0.05), 6(p< \\
0.01), 7(p<0.001) \text {, co-paeoniflorin at days } \\
6-7(p<0.05) \text {; Shortening of colon length: } \\
\text { Pre- and co-paeoniflorin }(p<0.05) \text {; } \\
\text { Histological score: Pre- and co-paeoniflorin } \\
(p<0.01) \text { vs. vehicle control. } \\
\text { Paeoniflorin-treated mice had lower ex- } \\
\text { pression of TLR4 protein and mRNA vs. } \\
\text { DSS only mice }(p<0.001) .\end{array}$ \\
\hline
\end{tabular}

RsDPLA Rhodobacter sphaeroides lipid A, i.p. intraperitoneal injection, $L P S$ lipopolysaccharide, $T N F$ - $\alpha$ tumor necrosis factor alpha, $I L-6$ interleukin 6 , CD14 cluster of differentiation 14, TLR4 toll-like receptor 4, MD2 myeloid differentiation factor 2, LOS lipooligosaccharide, BqLOS Bartonella quintana, $P B M C$ peripheral blood mononuclear cell, $I L-1 \beta$ interleukin 1 beta, $I L-8$ interleukin $8, A \beta O$ amyloid $\beta$ oligomers, $I C V$ intracerebroventricular injection, $C B Z$ carbamazepine, $N F-\kappa B$ nuclear factor kappaB, $S \operatorname{sn} B$ Sparstolonin B, $P T L$ parthenolide, $H B E$ human bronchial epithelial cell line, $A S$ allele specific, $C F T R$ cystic fibrosis transmembrane conductance regulator, $P M N$ polymorphonuclear leukocytes, $H E K$ human embryonic kidney, $M C P$ 1 monocyte chemoattractant protein 1, AO-I/AT-I atractylenolide I, MPO myeloperoxidase, CLP cecal ligation and puncture, $A A$ asiatic acid, $m R N A$ messenger RNA, $X N$ xanthohumol, $N O$ nitric oxide, $D S S$ dextran sulphate sodium, $D A I$ disease activity index

compared to E5531 [83]. Studies on eritoran have shown a positive effect against sepsis [83] and other inflammatory conditions $[84,85]$. This led to the development of other synthetic analogues such as TAK-242 and FP7 with antagonistic effects on the TLR4/MD2 complex to treat various inflammatory diseases such as neuroinflammation and influenza infections. Although the main focus of this study is on the therapeutic potentials of TLR 4 antagonists on intestinal inflammation, there are a limited number of studies, which used intestinal inflammation as a disease model. Therefore, studies which encompass different inflammatory diseases have been included and summarized in Table 2 in order to show the potential broader anti-inflammatory effects of TLR4 antagonism.

The most well-known TLR4 antagonist to enter the clinical phase was eritoran, followed by TAK-242; and although many synthetic TLR4 antagonists have been developed and studied, very few have actually made it into clinical trials, due to the limited evidence currently available. Table 3 summarises only the TLR4 antagonists that have been, or are, undergoing clinical trials in different inflammatory disease models. However, this will allow for a broader view of using TLR4 
Table 2 Summary of the effect of synthetic TLR4 antagonists in pre-clinical in vitro and in vivo research studies

\begin{tabular}{|c|c|c|}
\hline Study & Study model & TLR4 antagonist \\
\hline
\end{tabular}

Mullarkey et al. [83] Sepsis

In vivo: $\mathrm{C} 57 \mathrm{~B} 1 / 6$ mice, Hartley guinea pigs,

Fischer rats challenged with i.v. LPS

Kitazawa et al. [84] Acute liver failure (ALF)

In vivo: Wistar rats challenged with

D-galactosamine (GalN) and LPS

Liu et al. [85]

Sha et al. [86]

Inflammatory effects of ischemia-reperfusion in kidneys

In vivo: Fisher rats with kidney

nephrectomy and ischemia performed.

Endotoxin shock

TAK-242

In vivo: $\mathrm{BALB} / \mathrm{c}$ mice treated with LPS i.p.

(Resatorvid)

Kuno et al. [87]

Endotoxemia

In vivo: Hartley guinea pigs treated with LPS i.v.

Garate et al. [88]

Neuroinflammation

In vivo: Wistar Hannover rats restrained to induce stress.

Hua et al. [89]

Cerebral ischemia

In vivo: $\mathrm{C} 57 \mathrm{Bl} / 6$ mice induced with focal cerebral ischemia/reperfusion

Perrin-Cocon et al. [90]

Lethal influenza infection

In vitro: monocyte-derived dendritic cells (DCs) challenged with influenza virus, strain $\mathrm{A} / \mathrm{PR} / 8 / 34$

In vivo: $\mathrm{C} 57 \mathrm{~B} 1 / 6$ infected with mouse-adapted influenza virus, strain $\mathrm{A} / \mathrm{PR} / 8 / 34$
Mice:

E5564 $(100,300,1000 \mu \mathrm{g} / \mathrm{kg})$ co-treatment was associated with $37 \%, 81 \%$ and $93 \%$ inhibition of LPS-induced $(100 \mu \mathrm{g} / \mathrm{kg})$ response as measured by serum TNF- $\alpha$ levels, respectively ( $p<0.05$ vs. control).

Guinea pigs:

E5564 $(30,100,300 \mu \mathrm{g} / \mathrm{kg})$ co-treatment was associated with $29 \%, 57 \%$ and $94 \%$ inhibition of LPS-induced $(1000 \mu \mathrm{g} / \mathrm{kg})$ response as measured by serum TNF- $\alpha$ levels, respectively ( $p<0.05$ vs. control).

Rats:

E5564 $(10,100,1000 \mu \mathrm{g} / \mathrm{kg})$ co-treatment was associated with $84 \%, 97 \%$ and $100 \%$ inhibition of LPS-induced $(3 \mu \mathrm{g} / \mathrm{kg})$ response as measured by serum TNF- $\alpha$ levels, respectively ( $p<0.05$ vs. control).

Rats treated with E5564 after ALF $(500 \mathrm{mg} / \mathrm{kg} \mathrm{GalN}+$ $50 \mu \mathrm{g} / \mathrm{kg}$ LPS) displayed a decrease in serum TNF- $\alpha$ levels and had an improved survival rate of $42.9 \%$ compared to untreated rats $(p<0.05)$.

Rats treated with E5564 displayed a significant improvement in renal function as measured by serum creatinine levels $(p<0.05)$ and higher survival rates $(p<$ $0.05)$ vs. vehicle controls.

Pre-treatment of TAK-242 (0.1, 0.3, 1 and $3 \mathrm{mg} / \mathrm{kg})$ was associated with a decrease in LPS-induced $(10 \mathrm{mg} / \mathrm{kg})$ responses as measured by IL-6, IL-10, MIP-2, IL-1 $\beta$ and NO serum levels vs. vehicle control $(p<0.025)$. A $40 \%$ increase in survival rate of mice was also observed vs vehicle control $(p \leq 0.05)$.

Post-treatment of TAK-242 $(1 \mathrm{mg} / \mathrm{kg})$ was associated with a decrease in LPS-induced $(5 \mathrm{mg} / \mathrm{kg}$ ) response as measured by IL- 6 and MIP-2 serum levels vs. vehicle control $(p \leq 0.01)$. A survival rate of $45 \%$ was also observed vs. vehicle control $(p \leq 0.01)$.

TAK-242 (3 and $10 \mathrm{mg} / \mathrm{kg}$ ) pre-treatment was associated with a dose-dependent decline in colonic muscle tension ( $p=0.001$ and $p<0.001$, respectively) and mean arterial pressure ( $p=0.036$ and $p=0.004$, respectively) caused by LPS $(10 \mathrm{mg} / \mathrm{kg}$, i.v.). A $50 \%$ survival rate was observed when pre-treated with TAK-242 at $10 \mathrm{mg} / \mathrm{kg}$ vs. the $10 \%$ observed in the control group.

Pre-treatment of TAK-242 (0.5 mg/kg, i.v.) decreased expression of the pro-inflammatory enzymes: IL-1 $\beta$, COX-2 and iNOS expression levels, $p<0.05$ vs control, $p<0.05$ vs stress only group.

Treatment with TAK-242 $(3 \mathrm{mg} / \mathrm{kg})$ was associated with reduce levels of serum TNF receptor II, monocyte chemotactic protein-1, macrophage inflammatory protein- $1 \gamma$ and tissue inhibitor of metalloproteinases- 1 ( $p<0.05 \mathrm{vs.}$ untreated mice). An $8.8 \%$ reduction in brain infarct size and improved neurologic function score (6.73) were also observed ( $p<0.05$ vs. untreated mice).

In vitro:

FP7 $(1$ and $10 \mu \mathrm{M})$ treatment was associated with decreased levels of LPS-induced $(10 \mathrm{ng} / \mathrm{mL})$ responses as measured by supernatant levels of IL-8, IL-6, MIP- $1 \beta$, TNF- $\alpha$, IL-12 and IL-10 in both monocytes and DCs ( $p<0.05$ vs. LPS).

In vivo:

Mice treated with FP7 $(200 \mu \mathrm{g} / \mathrm{mouse}$, i.v. ) after influenza infection displayed reduced gene production of TNF- $\alpha$, 
Table 2 (continued)

\begin{tabular}{llll}
\hline Study & Study model & TLR4 antagonist & Outcome \\
\hline
\end{tabular}

Palmer et al. [91]

Facchini et al. [92]

Huggins et al. [93] Abdominal aortic aneurysm (AAA) In vivo: $\mathrm{C} 57 \mathrm{~B} / / 6$ mice induced with $\mathrm{AAA}$

Zhang et al. [94] In vitro: HUVEC challenged with LPS

Cardiovascular inflammatory-based diseases

In vitro: Human umbilical vein endothelial cells (HUVEC), THP-1 and mouse RAW-264.7 macrophages challenged with LPS

In vivo: Angiotensin II-infused apolipoprotein E-deficient mice

Inflammatory bowel disease

In vitro: Peripheral blood mononuclear cells and lamina propria mononuclear cells collected from patients with IBD

In vivo: $\mathrm{BALB} / \mathrm{c}$ mice with DSS administered in their water.

IAXO-102

Acute lung injury (ALI)

In vitro: Mouse RAW 264.7 macrophages challenged with LPS

In vivo: Sprague-Dawley rats with ALI induced by intratracheal LPS instillation

IL- $1 \beta$, IFN- $\beta$, murine IL- $8(p<0.01)$ and IL- $6(p<0.05)$ in the lungs. FP7-treated mice had decreased viral load $(\log$ FP7-treated titre $=4.1 \pm 0.39)$ vs. vehicle-treated mice (log vehicle-treated titre $=5.27 \pm 0.15)$ as measured by a virus titration assay $(p=0.0225)$.

In vitro:

FP7 $(0-10 \mu \mathrm{M})$ negatively regulated LPS-induced production $(100 \mathrm{ng} / \mathrm{mL})$ of pro-inflammatory cytokines in a dose-dependent manner:

THP-1: IL-8 $(p<0.001)$, IL-6 ( $p<0.01)$, MIP- $1 \alpha(p<$ $0.001)$ at $5 \mu \mathrm{M}$ and IL- $1 \beta(p<0.001)$ at $0.1,1,5 \mu \mathrm{M}$ vs. LPS.

RAW-264.7: p65 NF- $\kappa B$ at 1, 5, $10 \mu \mathrm{M}(p<0.001)$, IL-6 at $5 \mu \mathrm{M}(p<0.05), 10 \mu \mathrm{M}(p<0.001)$ and $\mathrm{p} 38 \mathrm{MAPK}$ at $0.1(p<0.05), 1(p<0.01), 5$ and $10 \mu \mathrm{M}(p<0.001)$ vs. LPS.

HUVEC: p38 MAPK and p65 NF-kB at 0.1, 0.5 and $1 \mu \mathrm{M}(p<0.01, p<0.05, p<0.01$, respectively $), \mathrm{MCP}-1$ at $1 \mu \mathrm{M}(p<0.05)$ vs. LPS.

In vivo:

FP7 (3 mg/kg/day) inhibited angiotensin II-driven production of pro-inflammatory proteins, and MIP- $1 \gamma$ and JNK phosphorylation ( $p<0.05$ vs. angiotensin II group).

In vitro:

FP7 at $10 \mu \mathrm{M}$ negatively regulated LPS-induced production $(100 \mathrm{ng} / \mathrm{mL})$ of pro-inflammatory cytokines: mRNA relative expression: TNF- $\alpha(p<0.001)$; IL-1 $\beta(p<$ $0.05)$; IL-6 $(p<0.05)$.

ELISA: TNF- $\alpha$, IL-1 $\beta$ and IL-6 $(p<0.05)$.

In vivo: FP7 $(250 \mu \mathrm{g} / \mathrm{kg})$ treatment was associated with a lower histological score ( $p<0.01 \mathrm{vs.} \mathrm{DSS)}$ and significantly reduced the release of inflammatory cytokines TNF- $\alpha(p<0.05)$, IL-1 $\beta(p<0.001)$ and IL-6 $(p<0.05)$.

\section{In vitro:}

IAXO-102 $(10 \mu \mathrm{M})$ blocked LPS-stimulated $(100 \mathrm{ng} / \mathrm{mL})$ production of JNK, ERK, p65 NF-KB ( $p<$ $0.05)$ and $\mathrm{p} 38, \mathrm{MCP}-1, \mathrm{IL}-8(p<0.01)$ vs. LPS.

In vivo:

IAXO-102 (3 mg/kg/day) blocked angiotensin II-induced response as measured by protein expression of JNK, ERK, p65, NF- $\mathrm{KB}(p<0.05)$ vs. angiotensin II only group. IAXO-102 also downregulated expression of MIP- $1 \gamma$ and TLR4 ( $p<0.05$ vs. angiotensin II group) and reduced incidence of AAA $(30 \%$ IAXO-102-treated vs. $86 \%$ angiotensin II group).

Chalcone derivatives - Compound 20

\section{In vitro:}

Fluorescent probe determined compound 20 is a specific inhibitor of MD2 $(\mathrm{KD}=189 \mu \mathrm{M})$. Addition of compound $20(10 \mu \mathrm{M})$ inhibited LPS-induced $(0.5$ $\mu \mathrm{g} / \mathrm{mL})$ secretion of TNF- $\alpha$, IL- $1 \beta$, COX-2 $(p<0.01)$ and IL-6 $(p<0.05)$ vs. LPS.

In vivo:

Compound $20(20 \mathrm{mg} / \mathrm{kg}$ ) reduced LPS-induced (5 mg/$\mathrm{kg}$ ) pulmonary edema as measure by the decrease in lung wet/dry weight ratio $(p<0.01)$ vs. LPS. Compound 20 also inhibited IL- $1 \beta$ secretion $(p<0.01)$ and MPO activity $(p<0.05)$ vs. LPS. 
Table 2 (continued)

\begin{tabular}{|c|c|c|c|}
\hline Study & Study model & TLR4 antagonist & Outcome \\
\hline Wang et al. [95] & $\begin{array}{l}\text { Septic shock and lung injury } \\
\text { In vitro: Mouse primary peritoneal } \\
\text { macrophages challenged with LPS } \\
\text { In vivo: C57B1/6 mice injected with LPS }\end{array}$ & $\begin{array}{l}\text { Curcumin analogues } \\
\text { - L48H37 }\end{array}$ & $\begin{array}{l}\text { In vitro: } \\
\text { Fluorescent probe determined } \mathrm{L} 48 \mathrm{H} 37 \text { is a specific } \\
\text { inhibitor of } \mathrm{MD} 2(\mathrm{KD}=11.3 \mu \mathrm{M}) \text {. } \mathrm{L} 48 \mathrm{H} 37(1,2.5,5 \text { or } \\
10 \mu \mathrm{M}) \text { inhibited LPS-induced }(0.5 \mu \mathrm{g} / \mathrm{mL}) \text { phos- } \\
\text { phorylation in a dose-dependent manner: ERK at } 1,2.5 \text {, } \\
5 \text { and } 10 \mu \mathrm{M}(p<0.01), \mathrm{p} 38 \text { at } 2.5 \mu \mathrm{M}(p<0.05), 5 \text { and } \\
10 \mu \mathrm{M}(p<0.01) \text {, and JNK at } 5 \text { and } 10 \mu \mathrm{M}(p<0.01) \text { vs. } \\
\text { LPS. L48H37 }(10 \mu \mathrm{M}) \text { inhibited secretion of TNF- } \alpha \text {, } \\
\text { IL-6, IL- } 1 \beta \text { and iNOS }(p<0.01 \text { vs. LPS-treated group); } \\
\text { IL-10 and COX-2 }(p<0.05 \text { vs. LPS-treated group). } \\
\text { In vivo: } \\
\text { L48H37-treated }(10 \mathrm{mg} / \mathrm{kg}) \text { mice had higher survival } \\
\text { rates vs. LPS }(20 \mathrm{mg} / \mathrm{kg} \text {, i.v.) ( } p<0.01) \text {. Pulmonary } \\
\text { damage and LPS-injured tissue structure of lungs was } \\
\text { amended. }\end{array}$ \\
\hline $\begin{array}{l}\text { Hodgkinson and Ye. } \\
\text { [96] }\end{array}$ & $\begin{array}{l}\text { In vitro inflammation model } \\
\text { In vitro: Human embryonic kidney (HEK) } \\
\text { 293-CD14- } \\
\text { MD2 cells challenged with LPS }\end{array}$ & $\begin{array}{l}\text { Statins } \\
\text { - Simvastatin } \\
\text { - Pravastatin }\end{array}$ & $\begin{array}{l}\text { Both simvastatin and pravastatin }(2 \mu \mathrm{M}) \text { pre-treatment } \\
\text { was associated with the inhibition of LPS-induced ( } 5 \\
\mathrm{ng} / \mathrm{mL}) \text { response as measured by supernatant concen- } \\
\text { trations of NF- } \mathrm{BB} \text {, IL- } 6 \text { and TNF- } \alpha(p<0.05 \text { vs. LPS). }\end{array}$ \\
\hline Katsargyris et al. [97] & $\begin{array}{l}\text { Carotid atherosclerotic plaques } \\
\text { Ex vivo: atherosclerotic plaques from } \\
\quad \text { patients }\end{array}$ & & $\begin{array}{l}\text { Patients who used statins had lower TLR4 expression in } \\
\text { their endothelial cells and atherosclerotic plaques vs. } \\
\text { non-statin patients ( } p=0.02 \text { and } p=0.03 \text {, respectively). } \\
\text { Prevalence cerebrovascular accident was } 18.6 \% \text { in } \\
\text { statin group vs. } 61.4 \% \text { of non-statin group (odds ratio } \\
\text { [95\% CI] } 0.14[0.07-0.31] p<0.001 \text { ). }\end{array}$ \\
\hline Fort et al. [98] & $\begin{array}{l}\text { Inflammatory bowel disease } \\
\text { BALB/c mice with DSS administered in } \\
\text { their water. }\end{array}$ & $\begin{array}{l}\text { Lipid A-mimetic } \\
\text { - CRX-526 }\end{array}$ & $\begin{array}{l}\text { CRX-526 }(2,10,50 \mu \mathrm{g}) \text { treatment was associated with a } \\
\text { lower DAI }(p=0.421,0.056,0.016 \text {, respectively) and } \\
\text { histological score }(p=0.032,0.008,0.008 \text {, respectively }) \\
\text { vs. DSS in a dose-dependent manner. }\end{array}$ \\
\hline
\end{tabular}

E5564 eritoran, $L P S$ lipopolysaccharide, $I V$ intravenous, $T N F-\alpha$ tumor necrosis factor alpha, $A L F$ acute liver failure, GalN D-galactosamine, i.p. intraperitoneal, Resatorvid TAK-242, IL-6 interleukin 6, IL-10 interleukin 10, MIP-2 macrophage inflammatory protein $2, I L-1 \beta$ interleukin 1 beta, $N O$ nitric oxide, $C O X-2$ cyclooxygenase 2 , iNOS nitric oxide synthase, $D C s$ dendritic cells, $I L-8$ interleukin $8, M I P-1 \beta$ macrophage inflammatory protein 1 beta, $I L-12$ interleukin $12, I F N-\beta$ interferon beta, $H U V E C$ human umbilical vein endothelial cells, THP-1 human acute monocytic leukemia cell, $M A P K$ mitogen-activated protein kinase, $M I P-1 \alpha$ macrophage inflammatory protein 1 alpha, MAPK mitogen-activated protein kinase, $M I P-1 \gamma$ macrophage inflammatory protein 1 gamma, $J N K$ c-Jun N-terminal kinase, IBD inflammatory bowel disease, DSS dextran sulphate sodium, $m R N A$ messenger RNA, $A A A$ abdominal aortic aneurysm, $H U V E C$ human umbilical vein endothelial cell, $E R K$ extracellular signal-regulated kinase, $A L I$ acute lung injury, $M D 2$ myeloid differentiation factor 2, $K D$ equilibrium dissociation constant, $H E K$ human embryonic kidney, $C D 14$ cluster of differentiation $14, D A I$ disease activity index

antagonists in inflammatory diseases to support its use in intestinal inflammation.

\section{Conclusions}

Both IBD and IM have significant effects on a patient's quality of life as well as economic and social burdens [51, 99, 100]. While the pathophysiology for chronic intestinal inflammation remains unknown, previous research has identified that TLR4 signalling in the intestinal tract is a critical regulator of intestinal immune homeostasis. The use of a TLR4 antagonist has potential as a novel therapeutic for IBD and IM patients whose disease pathogenesis relies heavily on TLR4 signalling. Previous studies have shown that inhibiting LPS-induced TLR4 stimulation with antagonists can reduce intestinal inflammation in animal models [101]. Regardless of how promising TLR4 antagonists are in the treatment of intestinal inflammation, there are still challenges in bioavailability and delivery. Nonetheless, anti-TLR4 therapies present a promising alternative for future innovative treatments for both IBD and IM. In the future, there is a need for tissue specific studies looking into these anti-TLR4 therapies in order to mimic the therapeutic setting of IBD and IM. 


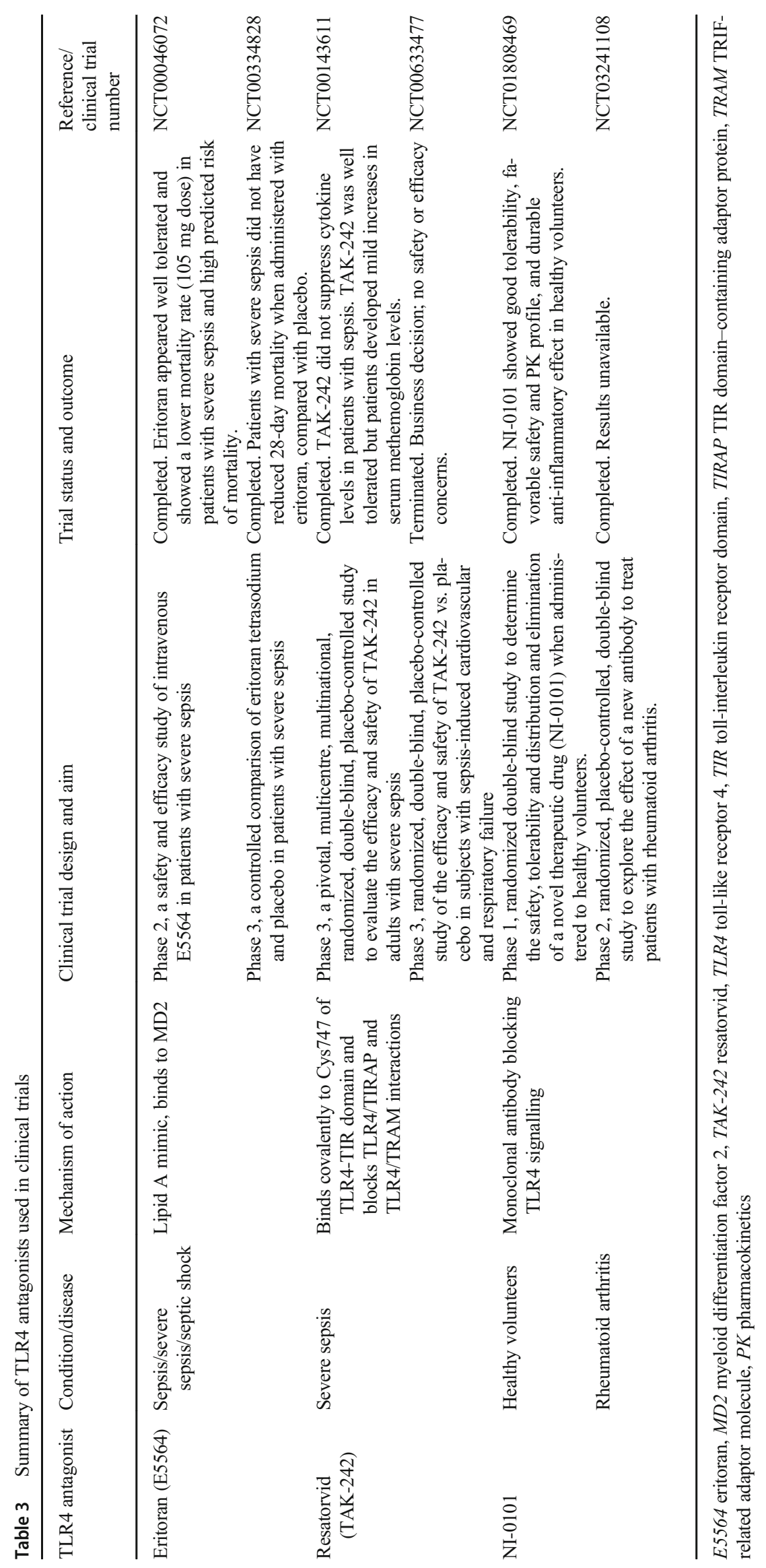


Authors' contribution Janine S.Y. Tam: Writing of the manuscript with input from all authors. Janet K. Coller: Provided critical feedback of the manuscript for important intellectual content. Patrick A. Hughes: Provided critical feedback of the manuscript for important intellectual content. Clive A. Prestidge: Provided critical feedback of the manuscript for important intellectual content. Joanne M. Bowen: Provided feedback and critical revision of the manuscript for important intellectual content, final approval of the manuscript.

\section{Compliance with ethical standards}

Conflict of interest JSYT, JKC, PAH, CAP, and JMB declare that they have no conflict of interest.

Disclaimer The authors are solely responsible for the data and the contents of the paper. In no way, the Honorary Editor-in-Chief, Editorial Board Members, the Indian Society of Gastroenterology or the printer/ publishers are responsible for the results/findings and content of this article.

\section{References}

1. Ananthakrishnan AN. Epidemiology and risk factors for IBD. Nat Rev Gastroenterol Hepatol. 2015;12:205-17.

2. Trotti A, Bellm LA, Epstein JB, et al. Mucositis incidence, severity and associated outcomes in patients with head and neck cancer receiving radiotherapy with or without chemotherapy: a systematic literature review. Radiother Oncol. 2003;66:253-62.

3. Akira S, Takeda K. Toll-like receptor signalling. Nat Rev Immunol. 2004;4:499-511.

4. Kawasaki T, Kawai T. Toll-like receptor signaling pathways. Front Immunol. 2014;5:461.

5. Kawai T, Akira S. TLR signaling. Cell Death Differ. 2006;13:816-25.

6. Worbs T, Hammerschmidt SI, Förster R. Dendritic cell migration in health and disease. Nat Rev Immunol. 2017;17:30-48.

7. Mowat AM. Anatomical basis of tolerance and immunity to intestinal antigens. Nat Rev Immunol. 2003;3:331-41.

8. Dong L, Li J, Liu Y, et al. Toll-like receptor 2 monoclonal antibody or/and toll-like receptor 4 monoclonal antibody increase counts of Lactobacilli and Bifidobacteria in dextran sulfate sodium-induced colitis in mice. J Gastroenterol Hepatol. 2012;27:110-9.

9. Heimesaat MM, Fischer A, Siegmund B, et al. Shift towards proinflammatory intestinal bacteria aggravates acute murine colitis via toll-like receptors 2 and 4. PLoS One. 2007;2:e662.

10. Gribar SC, Anand RJ, Sodhi CP, Hackam DJ. The role of epithelial toll-like receptor signaling in the pathogenesis of intestinal inflammation. J Leukoc Biol. 2008;83:493-8.

11. Takahashi K, Sugi Y, Hosono A, Kaminogawa S. Epigenetic regulation of TLR4 gene expression in intestinal epithelial cells for the maintenance of intestinal homeostasis. J Immunol. 2009;183: 6522-9.

12. Medzhitov R, Preston-Hurlburt P, Janeway CA Jr. A human homologue of the Drosophila toll protein signals activation of adaptive immunity. Nature. 1997;388:394-7.

13. Kawai T, Akira S. Toll-like receptor downstream signaling. Arthritis Res Ther. 2005;7:12-9.

14. Gay NJ, Gangloff M. Structure and function of toll receptors and their ligands. Annu Rev Biochem. 2007;76:141-65.

15. Liaunardy-Jopeace A, Gay NJ. Molecular and cellular regulation of toll-like receptor-4 activity induced by lipopolysaccharide ligands. Front Immunol. 2014;5:473.
16. Frantz S, Kobzik L, Kim Y-D, et al. Toll4 (TLR4) expression in cardiac myocytes in normal and failing myocardium. J Clin Invest. 1999;104:271-80.

17. Kielian T. Toll-like receptors in central nervous system glial inflammation and homeostasis. J Neurosci Res. 2006;83:711-30.

18. Taylor KR, Trowbridge JM, Rudisill JA, et al. Hyaluronan fragments stimulate endothelial recognition of injury through TLR4. J Biol Chem. 2004;279:17079-84.

19. Jilling T, Simon D, Lu J, et al. The roles of bacteria and TLR4 in rat and murine models of necrotizing enterocolitis. J Immunol. 2006; 177:3273-82.

20. Park BS, Song DH, Kim HM, et al. The structural basis of lipopolysaccharide recognition by the TLR4-MD-2 complex. Nature. 2009;458:1191-6.

21. Abreu MT, Vora P, Faure E, et al. Decreased expression of tolllike receptor-4 and MD-2 correlates with intestinal epithelial cell protection against dysregulated proinflammatory gene expression in response to bacterial lipopolysaccharide. J Immunol. 2001;167: 1609-16.

22. Blackwell TS, Christman JW. The role of nuclear factor- $\mathrm{K} B$ in cytokine gene regulation. Am J Respir Cell Mol Biol. 1997;17:39.

23. Hold GL, Berry S, Saunders KA, et al. The TLR4 D299G and T399I SNPs are constitutively active to up-regulate expression of TRIF-dependent genes. PLoS One. 2014;9:e111460.

24. Ferwerda B, McCall MB, Alonso S, et al. TLR4 polymorphisms, infectious diseases, and evolutionary pressure during migration of modern humans. Proc Natl Acad Sci U S A. 2007;104:16645-50.

25. Weinstein JR, Schulze J, Lee RV, et al. Functional polymorphisms in toll-like receptor 4 are associated with worse outcome in acute ischemic stroke patients. Neuroreport. 2014;25:580-4.

26. Fukata $\mathrm{M}$, Arditi $\mathrm{M}$. The role of pattern recognition receptors in intestinal inflammation. Mucosal Immunol. 2013;6:451-63.

27. Brown M, Hughes KR, Moossavi S, et al. Toll-like receptor expression in crypt epithelial cells, putative stem cells and intestinal myofibroblasts isolated from controls and patients with inflammatory bowel disease. Clin Exp Immunol. 2014;178:28-39.

28. Belmonte L, Beutheu Youmba S, Bertiaux-Vandaele N, et al. Role of toll like receptors in irritable bowel syndrome: differential mucosal immune activation according to the disease subtype. PLoS One. 2012;7:e42777.

29. Franchimont D, Vermeire S, El Housni H, et al. Deficient hostbacteria interactions in inflammatory bowel disease? The toll-like receptor (TLR)-4 Asp299gly polymorphism is associated with Crohn's disease and ulcerative colitis. Gut. 2004;53:987-92.

30. Fukata M, Chen A, Vamadevan AS, et al. Toll-like receptor-4 promotes the development of colitis-associated colorectal tumors. Gastroenterology. 2007;133:1869-81.

31. Fukata M, Michelsen KS, Eri R, et al. Toll-like receptor-4 is required for intestinal response to epithelial injury and limiting bacterial translocation in a murine model of acute colitis. Am J Physiol Gastrointest Liver Physiol. 2005;288:1055-65.

32. Zhang J, Dou W, Zhang E, et al. Paeoniflorin abrogates DSSinduced colitis via a TLR4-dependent pathway. Am J Physiol Gastrointest Liver Physiol. 2014;306:27-36.

33. Liu Y, Zhang Z, Wang L, et al. TLR4 monoclonal antibody blockade suppresses dextran-sulfate-sodium-induced colitis in mice. $\mathrm{J}$ Gastroenterol Hepatol. 2010;25:209-14.

34. Fort MM, Mozaffarian A, Stöver AG, et al. A synthetic TLR4 antagonist has anti-inflammatory effects in two murine models of inflammatory bowel disease. J Immunol. 2005;174:6416-23.

35. Ungaro R, Fukata M, Hsu D, et al. A novel toll-like receptor 4 antagonist antibody ameliorates inflammation but impairs mucosal healing in murine colitis. Am J Physiol Gastrointest Liver Physiol. 2009;296:G1167-G79. 
36. Wardill HR, Choo JM, Dmochowska N, et al. Acute colitis drives tolerance by persistently altering the epithelial barrier and innate and adaptive immunity. Inflamm Bowel Dis. 2019;25:1196-207.

37. Cho JH. The genetics and immunopathogenesis of inflammatory bowel disease. Nat Rev Immunol. 2008;8:458-66.

38. de Mattos BRR, Garcia MPG, Nogueira JB, et al. Inflammatory bowel disease: an overview of immune mechanisms and biological treatments. Mediat Inflamm. 2015;2015:493012.

39. Itzkowitz SH, Yio X. Inflammation and cancer IV. Colorectal cancer in inflammatory bowel disease: the role of inflammation. Am J Physiol Gastrointest Liver Physiol. 2004;287:G7-G17.

40. Molodecky NA, Soon IS, Rabi DM, et al. Increasing incidence and prevalence of the inflammatory bowel diseases with time, based on systematic review. Gastroenterology. 2012;142:46-54.

41. Gibson PR, Weston AR, Shann A, et al. Relationship between disease severity, quality of life and health-care resource use in a cross-section of Australian patients with Crohn's disease. J Gastroenterol Hepatol. 2007;22:1306-12.

42. Gibson PR, Vaizey C, Black CM, et al. Relationship between disease severity and quality of life and assessment of health care utilization and cost for ulcerative colitis in Australia: a cross-sectional, observational study. J Crohns Colitis. 2014;8:598-606.

43. Sartor RB. Mechanisms of disease: pathogenesis of Crohn's disease and ulcerative colitis. Nat Clin Pract Gastroenterol Hepatol. 2006;3:390-407.

44. Garud S, Peppercorn MA. Ulcerative colitis: current treatment strategies and future prospects. Ther Adv Gastroenterol. 2009;2: 99-108.

45. Veauthier B, Hornecker JR. Crohn's disease: diagnosis and management. Am Fam Physician. 2018;98:661-9.

46. Jones JA, Avritscher EB, Cooksley CD, et al. Epidemiology of treatment-associated mucosal injury after treatment with newer regimens for lymphoma, breast, lung, or colorectal cancer. Support Care Cancer. 2006;14:505-15.

47. Lalla RV, Bowen J, Barasch A, et al. MASCC/ISOO clinical practice guidelines for the management of mucositis secondary to cancer therapy. Cancer. 2014;120:1453-61.

48. Duncan M, Grant G. Oral and intestinal mucositis - causes and possible treatments. Aliment Pharmacol Ther. 2003;18:853-74.

49. Cario E. Toll-like receptors in the pathogenesis of chemotherapyinduced gastrointestinal toxicity. Curr Opin Support Palliat Care. 2016;10:157-64.

50. Bowen JM, Gibson RJ, Coller JK, et al. Systematic review of agents for the management of cancer treatment-related gastrointestinal mucositis and clinical practice guidelines. Support Care Cancer. 2019;27:4011-22.

51. Elting LS, Cooksley C, Chambers M, et al. The burdens of cancer therapy. Clinical and economic outcomes of chemotherapyinduced mucositis. Cancer. 2003;98:1531-9.

52. Sonis ST, Elting LS, Keefe D, et al. Perspectives on cancer therapy-induced mucosal injury: pathogenesis, measurement, epidemiology, and consequences for patients. Cancer. 2004;100: 1995-2025.

53. Wardill HR, Gibson RJ, Van Sebille YZA, et al. Irinotecaninduced gastrointestinal dysfunction and pain are mediated by common TLR4-dependent mechanisms. Mol Cancer Ther. 2016;15:1376-86.

54. Cario E, Podolsky DK. Differential alteration in intestinal epithelial cell expression of toll-like receptor 3 (TLR3) and TLR4 in inflammatory bowel disease. Infect Immun. 2000;68:7010-7.

55. Pugazhendhi S, Jayakanthan K, Pulimood AB, Ramakrishna BS. Cytokine gene expression in intestinal tuberculosis and Crohn's disease. Int J Tuberc Lung Dis. 2013;17:662-8.

56. Abreu MT, Arnold ET, Thomas LS, et al. TLR4 and MD-2 expression is regulated by immune-mediated signals in human intestinal epithelial cells. J Biol Chem. 2002;277:20431-7.
57. Strittmatter W, Weckesser J, Salimath PV, et al. Nontoxic lipopolysaccharide from Rhodopseudomonas sphaeroides ATCC 17023. J Bacteriol. 1983;155:153-8.

58. Anwar MA, Panneerselvam S, Shah M, et al. Insights into the species-specific TLR4 signaling mechanism in response to Rhodobacter sphaeroides lipid A detection. Sci Rep. 2015;5:7657.

59. Molteni M, Bosi A, Rossetti C. Natural products with toll-like receptor 4 antagonist activity. Int J Inflam. 2018;2018:2859135.

60. Schink A, Neumann J, Leifke AL, et al. Screening of herbal extracts for TLR2- and TLR4-dependent anti-inflammatory effects. PLOS One. 2018;13:e203907-e.

61. Qureshi N, Takayama K, Kurtz R. Diphosphoryl lipid A obtained from the nontoxic lipopolysaccharide of Rhodopseudomonas sphaeroides is an endotoxin antagonist in mice. Infect Immun. 1991;59:441-4.

62. Malgorzata-Miller G, Heinbockel L, Brandenburg K, et al. Bartonella quintana lipopolysaccharide (LPS): structure and characteristics of a potent TLR4 antagonist for in-vitro and in-vivo applications. Sci Rep. 2016;6:34221.

63. Wang A, Xiao Z, Zhou L, et al. The protective effect of atractylenolide I on systemic inflammation in the mouse model of sepsis created by cecal ligation and puncture. Pharm Biol. 2016;54:146-50.

64. Balducci C, Frasca A, Zotti M, et al. Toll-like receptor 4-dependent glial cell activation mediates the impairment in memory establishment induced by beta-amyloid oligomers in an acute mouse model of Alzheimer's disease. Brain Behav Immunol. 2017;60: 188-97.

65. Yuan K, Huang G, Zhang S, et al. Celastrol alleviates arthritis by modulating the inflammatory activities of neutrophils. J Tradit Chin Med Sci. 2017;4:50-8.

66. Kirikae T, Schade FU, Kirikae F, et al. Diphosphoryl lipid A derived from the lipopolysaccharide (LPS) of Rhodobacter sphaeroides ATCC 17023 is a potent competitive LPS inhibitor in murine macrophage-like J774.1 cells. FEMS Immunol Med Microbiol. 1994;9:237-43.

67. De Paola M, Mariani A, Bigini P, et al. Neuroprotective effects of toll-like receptor 4 antagonism in spinal cord cultures and in a mouse model of motor neuron degeneration. Mol Med. 2012;18: 971-81.

68. Iori V, Iyer AM, Ravizza T, et al. Blockade of the IL-1R1/TLR4 pathway mediates disease-modification therapeutic effects in a model of acquired epilepsy. Neurobiol Dis. 2017;99:12-23.

69. Yao P, Tan F, Gao H, et al. Effects of probiotics on Toll-like receptor expression in ulcerative colitis rats induced by 2,4,6trinitro-benzene sulfonic acid. Mol Med Report. 2017;15:197380.

70. Chu M, Ding R, Chu ZY, et al. Role of berberine in anti-bacterial as a high-affinity LPS antagonist binding to TLR4/MD-2 receptor. BMC Complement Altern Med. 2014;14:89.

71. Liang $\mathrm{Q}, \mathrm{Wu} \mathrm{Q}$, Jiang J, et al. Characterization of sparstolonin $\mathrm{B}$, a Chinese herb-derived compound, as a selective toll-like receptor antagonist with potent anti-inflammatory properties. J Biol Chem. 2011;286:26470-9.

72. Li S, Gao X, Wu X, et al. Parthenolide inhibits LPS-induced inflammatory cytokines through the toll-like receptor 4 signal pathway in THP-1 cells. Acta Biochim Biophys Sin. 2015;47: 368-75.

73. Saadane A, Masters S, DiDonato J, et al. Parthenolide inhibits IkappaB kinase, NF-kappaB activation, and inflammatory response in cystic fibrosis cells and mice. Am J Respir Cell Mol Biol. 2007;36:728-36.

74. Gradišar H, Keber MM, Pristovšek P, et al. MD-2 as the target of curcumin in the inhibition of response to LPS. J Leukoc Biol. 2007;82:968-74. 
75. Zhu H-T, Bian C, Yuan J-C, et al. Curcumin attenuates acute inflammatory injury by inhibiting the TLR4/MyD88/NF-kB signaling pathway in experimental traumatic brain injury. $\mathrm{J}$ Neuroinflammation. 2014;11:59.

76. Zhang JL, Huang WM, Zeng QY. Atractylenolide I protects mice from lipopolysaccharide-induced acute lung injury. Eur J Pharmacol. 2015;765:94-9.

77. Li Z, Xiao X, Yang M. Asiatic acid inhibits lipopolysaccharideinduced acute lung injury in mice. Inflammation. 2016;39:1642-8.

78. Lee JY, Lee BH, Kim ND, et al. Celastrol blocks binding of lipopolysaccharides to a Toll-like receptor4/myeloid differentiation factor 2 complex in a thiol-dependent manner. J Ethnopharmacol. 2015;172:254-60.

79. Cho YC, Kim HJ, Kim YJ, et al. Differential anti-inflammatory pathway by xanthohumol in IFN-gamma and LPS-activated macrophages. Int Immunopharmacol. 2008;8:567-73.

80. Barochia A, Solomon S, Cui X, et al. Eritoran tetrasodium (E5564) treatment for sepsis: review of preclinical and clinical studies. Expert Opin Drug Metab Toxicol. 2011;7:479-94.

81. Kawata T, Bristol JR, Rossignol DP, et al. E5531, a synthetic nontoxic lipid A derivative blocks the immunobiological activities of lipopolysaccharide. Br J Pharmacol. 1999;127:853-62.

82. Kobayashi S, Kawata T, Kimura A, et al. Suppression of murine endotoxin response by E5531, a novel synthetic lipid A antagonist. Antimicrob Agents Chemother. 1998;42:2824-9.

83. Mullarkey M, Rose JR, Bristol J, et al. Inhibition of endotoxin response by E5564, a novel Toll-like receptor 4-directed endotoxin antagonist. J Pharmacol Exp Ther. 2003;304:1093-102.

84. Kitazawa T, Tsujimoto T, Kawaratani H, et al. Salvage effect of E5564, Toll-like receptor 4 antagonist on d-galactosamine and lipopolysaccharide-induced acute liver failure in rats. J Gastroenterol Hepatol. 2010;25:1009-12.

85. Liu M, Gu M, Xu D, et al. Protective effects of Toll-like receptor 4 inhibitor eritoran on renal ischemia-reperfusion injury. Transplant Proc. 2010;42:1539-44.

86. Sha T, Sunamoto M, Kitazaki T, et al. Therapeutic effects of TAK-242, a novel selective Toll-like receptor 4 signal transduction inhibitor, in mouse endotoxin shock model. Eur J Pharmacol. 2007;571:231-9.

87. Kuno M, Nemoto K, Ninomiya N, et al. The novel selective tolllike receptor 4 signal transduction inhibitor tak-242 prevents endotoxaemia in conscious Guinea-pigs. Clin Exp Pharmacol Physiol. 2009;36:589-93.

88. Garate I, Garcia-Bueno B, Madrigal JL, et al. Toll-like 4 receptor inhibitor TAK-242 decreases neuroinflammation in rat brain frontal cortex after stress. J Neuroinflammation. 2014;11:8.

89. Hua F, Tang H, Wang J, et al. TAK-242, an antagonist for Tolllike receptor 4, protects against acute cerebral ischemia/reperfusion injury in mice. J Cereb Blood Flow Metab. 2015;35:536-42.
90. Perrin-Cocon L, Aublin-Gex A, Sestito SE, et al. TLR4 antagonist FP7 inhibits LPS-induced cytokine production and glycolytic reprogramming in dendritic cells, and protects mice from lethal influenza infection. Sci Rep. 2017;7:40791.

91. Palmer C, Peri F, Neumann F, et al. The synthetic glycolipidbased TLR4 antagonist FP7 negatively regulates in vitro and in vivo haematopoietic and non-haematopoietic vascular TLR4 signalling. Innate Immun. 2018;24:411-21.

92. Facchini FA, Di Fusco D, Barresi S, et al. Effect of chemical modulation of toll-like receptor 4 in an animal model of ulcerative colitis. Eur J Clin Pharmacol. 2020;76:409-18.

93. Huggins C, Pearce S, Peri F, et al. A novel small molecule TLR4 antagonist (IAXO-102) negatively regulates non-hematopoietic toll like receptor 4 signalling and inhibits aortic aneurysms development. Atherosclerosis. 2015;242:563-70.

94. Zhang Y, Wu J, Ying S, et al. Discovery of new MD2 inhibitor from chalcone derivatives with anti-inflammatory effects in LPSinduced acute lung injury. Sci Rep. 2016;6:25130.

95. Wang Y, Shan X, Dai Y, et al. Curcumin analog L48H37 prevents lipopolysaccharide-induced TLR4 signaling pathway activation and sepsis via targeting MD2. J Pharmacol Exp Ther. 2015;353: 539-50.

96. Hodgkinson CP, Ye S. Statins inhibit toll-like receptor 4-mediated lipopolysaccharide signaling and cytokine expression. Pharmacogenet Genomics. 2008;18:803-13.

97. Katsargyris A, Klonaris C, Tsiodras S, et al. Statin treatment is associated with reduced toll-like receptor 4 immunohistochemical expression on carotid atherosclerotic plaques: a novel effect of statins. Vascular. 2011;19:320-6.

98. Fort MM, Mozaffarian A, Stöver AG, et al. A synthetic TLR4 antagonist has anti-inflammatory effects in two murine models of inflammatory bowel disease. J Immunol. 2005;174:6416.

99. Rubin DT, Mody R, Davis KL, et al. Real-world assessment of therapy changes, suboptimal treatment and associated costs in patients with ulcerative colitis or Crohn's disease. Aliment Pharmacol Ther. 2014;39:1143-55.

100. Cohen RD, Yu AP, Wu EQ, et al. Systematic review: the costs of ulcerative colitis in Western countries. Aliment Pharmacol Ther. 2010;31:693-707.

101. Kessel A, Toubi E, Pavlotzky E, et al. Treatment with glutamine is associated with down-regulation of Toll-like receptor-4 and myeloid differentiation factor 88 expression and decrease in intestinal mucosal injury caused by lipopolysaccharide endotoxaemia in a rat. Clin Exp Immunol. 2008;151:341-7.

Publisher's note Springer Nature remains neutral with regard to jurisdictional claims in published maps and institutional affiliations. 